\title{
A Library List of Scientific Books.
}

$A$ BOUT two years ago the Washington Academy of Sciences published a list of one hundred popular books in science suitable for inclusion in public libraries. The list has since been revised, and is reprinted below. The original list included the titles of forty-three books by British authors, but many of these have now been omitted as the volumes are out of print. All the works in the present list are obtainable through booksellers in the usual way. As the list was compiled for American libraries, the majority of the books mentioned in it are by American authors. We know of no similar list for British libraries, but one would no doubt be welcomed by librarians and others. Though librarians may be able to discover which books are interesting, they have no easy way of finding out which of such books are trustworthy and which are not merely unorthodox but misleading or misinforming.

In inviting correspondents to assist in preparing the list subjoined, the Committee of the Washington Academy of Sciences asked that the tests to be applied in selection of books should be as follows: "(I) The book must be readable; if the average visitor to the library takes the book home, it will interest him so much that he will read it through, and will come back to ask the librarian for another on the same subject. (2) It must be accurate; preferably wntten by one who knows his subject at first hand. Mthor points are: (3) up-to-dateness; (4) small bulk ; (5) attractive binding, type, and illustrations

"The relative number of books in different branches of science is not fixed. For example, a good book in mathematics may be substituted for a poor book in anthropology, provided anthropology is not thereby left wholly unrepresented."

The Committee has performed a useful service in selecting one hundred books which it feels fairly sure are scientifically trustworthy, and believes to be readable. It is obvious that a list of this kind must be subject to revision, and indeed should be revised frequently to keep up with the progress of science and the publication of books better adapted to the purpose. The Committee adds : "In general, it need hardly be said that even a tried and tested list can never be completely satisfactory, for the simple reason that there is no such person as the 'average reader.' Every individual has his own foundation of natural capacity and education, and his own background of experience and interests. We therefore need one series of lists covering all types of capacity, another series differentiated according to kind and duration of education, another series distributed according to age and to variety of experience, and still another adapted to the varied types of man's interests. Provided with such a set of lists we could name twenty-five scientific books which would be almost certain to interest keenly any given individual. Lacking such provision, we can only hope, on behalf of the very general list herewith submitted, that every reader who can be induced to read anything at all serious will find on the list a few books which appeal to him strongly, and that none of the other books will give him the impression that science makes reading-matter which is difficult or forbidding."

\section{Generai Scrence.}

I. J. Arthur Thomson, Editor. The Outline of Science.

2. Thomas Henry Huxley. Selections from Huxley.

NO. 28 I 6. VOL. I I 2$]$
MaN.

3. Edward L. Thorndike. The Human Nature Club.

4. William James. Psychology.

5. Robert S. Woodworth. Psychology ; a Study of Mental Life.

6. Henry Fairfield Osborn. Men of the Old Stone Age ; their Environment, Life, and Art.

7. O. T. Mason. The Origins of Invention.

8. O. T. Mason. Woman's Share in Primitive Culture.

9. Walter Hough. The Hopi Indians.

ro. E. V. MCCollum. The Newer Knowledge of Nutrition.

II. H. C. Sherman. Food Products.

I2. Walter H. Eddy. The Vitamine Manual; a Presentation of Essential Data about the New Food Factors.

I3. E. O. Jordan. Food Poisoning.

I4. William Williams KeEn. Medical Research and Human Welfare.

15. Ellsworth Huntington. Civilization and Climate.

\section{Heredity.}

I6. Chardes Darwin. The Origin of Species.

I7. E. M. EAsT and D. F. Jones. Inbreeding and Outbreeding.

i8. W. D. Castle, J. M. Coulter, C. B. Davenport, E. M. EAST, and W. L. Tower. Heredity and Eugenics.

I9. T. H. MoRGAN. A Critique of the Theory of Evolution.

20. E. G. ConkLIN. Heredity and Environment.

21. Francis Galton. Hereditary Genius,

22. Paul Popenoe and R. H, Johnson. Applied Eugenics.

\section{Biology.}

23. J. Arthur Thomson. The Wonder of Life. 24. J. Arthur Thomson. The Haunts of Life. 25. E. L. Bouvier. The Psychic Life of Insects. 26. Winterton C. Curtis. Science and Human Affairs.

27. Wriltam A. Locy. Biology and its Makers.

\section{ZoOLOGY.}

28. A. B. Buckley. The Winners in Life's Race. 29. E. W. Nelson. Wild Animals of North America.

3o. Theodore Roosevelt. African Game Trails. 3r. C. W. BeEbe. Jungle Peace.

32. Witmer Stone and W. E. Cram. American Animals ; a Popular Guide to the Mammals of North America north of Mexico.

33. Frank M. Chapman. Camps and Cruises of an Ornithologist.

34. J. H. FABRE, Social Life in the Insect World.

35. Maurice Maeterlinck. The Life of the Bee.

36. Oliver P. Jenkins. Interesting Neighbors,

37. W. S. Blatchley. Gleanings from Nature.

38. Alfred G. Mayer. Sea-shore Life.

\section{Botany.}

39. W. F. Ganong. The Living Plant; a Description and Interpretation of its Functions and Structure.

40. W. J. V. Osterhout. Experiments with Plants. 4I. Paul Sorauer. A Popular Treatise on the Physiology of Plants for the use of Gardeners or for Students of Horticulture and Agriculture. 
42. MARCEI E. Hardy. The Geography of Plants.

43. ChARLES DARWIN. Insectivorous Plants.

44. C. W. Townsend. Sand Dunes and Salt Marshes.

Microscopic LifE.

45. René Valery-Radot. Louis Pasteur, his Life and Labours.

\section{PaLeONTOLOGY.}

46. F, A. Lucas. Animals of the Past.

47. H. N. Hutchinson. Extinct Monsters and Creatures of Other Days; a Popular Account of some of the Larger Forms of Ancient Animal Life.

Geology and Geography.

48. J. W. Gregory. Geology of To-day.

49. Hallam Hawkesworth. The Strange Adventures of a Pebble.

5o. R. S. LulL and others. The Evolution of the Earth and its Inhabitants.

5r. T. C. Chamberlin. Origin of the Earth.

52. George P. Merrill. The First One Hundred Years of American Geology.

53. Ellen Churchili. Semple. Influences of Geographic Environment.

54. J. E. Spurr, Editor. Political and Commercia Geology and the World's Mineral Resources.

55. Albert P. Brigham. Geographic Influences in American History.

Geologic Agents.

56. John Tyndall. The Forms of Water in Cloud's and Rivers, Ice and Glaciers.

57. T. G. Bonney. The Work of Rains and Rivers.

58. T. G. Bonney. Volcanoes, their Structure and Significance.

59. Israer C. Russell. Volcanoes of North America.

6o. Charles Davison. The Origin of Earthquakes.

\section{Meteorology}

6I. R. G. K. LempFert. Weather Science.

62. R. DE C. WARD. Climate, considered especially in Relation to Man.

THE OCEAN.

63. John Murray. The Ocean.

RoCks AND Minerals.

64. Grenville A. J. Cole. Rocks and their Origins.

AsTRONOMY.

65. Robert S. Ball. The Story of the Heavens.

66. F. W. Dyson. Astronomy.

67. George E. Hale. The New Heavens.
68. Charles G. Abbot. The Sun

69. IsABEL M. Lewis. Splendors of the Sky.

7o. Kelvin McKready. A Beginner's Star Book.

7I. H. H. Turner. A Voyage through Space.

72. Arthur Berry. A Short History of Astronomy.

\section{CHEMisTRY.}

73. E. E. Slosson. Creative Chemistry.

74. El.Lwood HendRICK. Everyman's Chemistry.

75. Henry C. Fulrer. The Story of Drugs.

76. Jean Henri Fabre. The Wonder Book of Chemistry.

77. Robert Kennedy Duncan. The Chemistry of Commerce.

78. Geoffrey Martin. Modern Chemistry and its Wonders.

79. Frederick Soddy. The Interpretation of Radium.

8o. F. P. Venable, A Short History of Chemistry.

8I. Edgar Fahs Smith. Chemistry in America.

Physics.

82. Frederick Soddy. Matter and Energy.

83. JoHN Mills. Within the Atom.

84. Albert Einstein. Relativity.

85. J. A. Fleming. Waves and Ripples in Water, Air, and Aether.

86. Dayton C. Mrleer. The Science of Musical Sounds.

87. WILIIAM BRAgG. The World of Sound.

88. MARION Luckiesrr. Color and its Applications.

89. C. V. Boys. Soap Bubbles : their Colours and the Forces which Mould them.

9o. ERnst Mach. Popular Scientific Lectures.

9I. Frederick Soddy. Science and Iife.

Mathematics.

92. A. N. Whitehead. Introduction to Mathematics.

93. Levi Leonard Conant. The Number Concept, its Origin and Development.

94. John Wesley Young. Lectures on the Fundamental Concepts of Algebra and Geometry.

95. JAMEs Byrnie Shaw. Lectures on the Philosophy of Mathematics.

96. Augustus De Morgan. On the Study and Difficulties of Mathematics.

97. David Eugene Smith. Number Stories of Long Ago.

History OF SCIENCE.

98. Walter Libby. An Introduction to the History of Science.

99. W. T. SEDGwick and H. W. Tyler. A Short History of Science.

Ioo. ANDREW D. WHite. A History of the Warfare of Science with Theology in Christendom.

\section{The Zermatt Meeting of the Swiss Society of Natural Science.}

THE ro4th meeting of the Helvetic Society of Natural Science was held at Zermatt on August 30-September 2. On the evening of the first day, after a business meeting in which Lucerne was chosen as the meeting-place for next year, the Society was welcomed by the local and cantonal authorities at a soirée given by the Science Society of the Rhone Valley, called the Murithienne. The next day, which was very wet, was devoted appropriately to business: general meeting with speeches in the morning; sectional meetings in the afternoon.

M. le Chanoine Besse, curé of Riddes, who had been chosen as annual president, took the opportunity of his opening address piously to recall the names and the lifework of some of the most prominent savants of the valley. A member himself of the Congregation of St. Bernard, he was able to point to the long tale of patient study pursued by successive members of the same body; in particular he sketched the life of Laurent-Joseph Murith, I742-I8r6, geologist, conchologist, ornithologist, entomologist, as well as archæologist, who lived just long enough to be one of the first members of the infant Helvetic Society. Among the other men whose lives he told in impressively simple language I would only mention that of Walther Ritz, I878-I909, the brilliant young No. 28 I6, vol. II 2$]$ 